Mediterranean Journal of Humanities mjh.akdeniz.edu.tr III/1, 2013, 137-144

\title{
Methods and Techniques of Foreign Language Teachers Working with Young Learners in EFL Classes
}

\author{
Ingilizce Öğretmenleri’nin Çocuklara Yabancı Dil Öğretiminde Kullandıkları \\ Yöntem ve Teknikler
}

\section{Binnur GENÇ ÍLTER*}

\begin{abstract}
Foreign language teaching has been a very serious problem in Turkey for many years. This may be due to different factors such as: the students, the language teachers and the methods employed in EFL classes. The aim in this study was to determine which methods and techniques language teachers for young learners at MEB mostly use in their classes and how they usually plan the activities and motivate young learners. It is a descriptive study based upon quantitative data collection in the academic year 2011-2012, in Antalya, Kepez region and contains language teachers who are teaching for young learners at Ministry of National Education (MNA). 200 language teachers were surveyed, and the results obtained were analysed using SPSS. The data obtained showed which methods and techniques were used by language teachers depending on their graduation, training and experience. The results were discussed and the methods employed by language teachers were determined. After data analysis, suggestions for language teachers were provided.
\end{abstract}

Keywords: Foreign language methods, techniques, teaching foreign language to young learners

Özet: Yabancı dil öğretimi Türkiye'de her zaman ciddi bir sorundur. Bu sorun bazen öğrenciden, bazen de yabancı dil öğretmeni ve kullanılan yöntemlerden kaynaklanmaktadır. Bu çalışmanın amacı MEB İlköğretim okullarında görev yapan İngilizce öğretmenlerinin hangi yöntemleri kullandıkları, etkinlikleri nasıl planladıkları ve öğrencileri nasıl daha iyi güdüleyebildikleri konusuna açıklı getirmektir. Bu araştırma Antalya İli Kepez İlçesi MEB İlköğretim okullarında 2011-2012 eğitim-öğretim yılında çocuklara yabancı dil öğreten İngilizce öğretmenlerine uygulanan anketi kapsayan betimsel bir çalışmadır. MEB'de çalışan İngilizce öğretmenlerinin en çok kullandıkları yöntem ve teknikleri öğrenmek için 200 İngilizce öğretmenine bir anket uygulanmıştır. Elde edilen bulgular SPSS'te analiz edilerek öğretmenlerin sınıf içinde hangi yöntemleri ve teknikleri daha etkili kullanabildikleri belirlenmiştir. Çocuklara yabancı dil öğreten öğretmenlerin en çok kullandıkları yöntem ve teknikler tartışılmış ve İngilizce öğretmenlerinin daha etkin kullanabilecekleri teknikler öneri olarak ortaya konmuştur.

Anahtar sözcükler: Yabancı dil öğretim yöntemleri, teknikler, çocuklara yabancı dil öğretimi

Language teaching is one of the most important processes in the global world. Language teaching contains not only knowledge of foreign language but experience which leads to the teachers in a positive way. Bloom (1989) indicates that schools provide well-planned activities for children, on the other hand, families and their environment cannot organize language teaching regularly. Teachers have great roles for planning and in determining the goals of the learners. According to Bursalıoğlu (1994), Sönmez (1994) and Azar (2011), teachers should give im-

\footnotetext{
*Yrd. Doç. Dr., Akdeniz Üniversitesi, Eğitim Fakültesi, Yabancı Diller Eğitimi Böl., Antalya, bgilter@akdeniz.edu.tr
} 
portance to their own improvement and be aware of new trends in their field. In order to help their young students, they should put their objectives into an active process.

Jones, \& Jones (1998) claim that a good language teacher should understand children's needs and communicate with them in social contexts. Brooks (1987) indicates that children can learn languages when teachers use correct methods and connect new information with their previous knowledge. In TED's book (2009), teachers are defined as people setting teaching objectives and helping students as a guide in this process. They should also understand the children's point of view.

For Harmer (2005), language teachers should be student-centered and make the students comprehend the topics clearly. Larsen-Freeman (2010) explains the methods and techniques but mentions that these methods and techniques mostly depend on the language teachers' experience and teaching skills. They can change the techniques and adopt materials by developing appropriate tasks and activities according to their students' needs. Vale and Feunteun (2002) think that good language teachers should quickly analyze the learners and change their methods during the class period.

Wright et alii (2007) think that using games are always effective for young language learners so language teachers should use games during their teaching. Roth (1998) mentions that card games, action games, stories, videos, songs and rhymes improve children's language skills and vocabulary. Brewster et alii (2004) say that children feel better and content when they learn in democratic, independent classrooms if their language teachers use more creative and communicative activities. According to Scott and Ytreberg (2010), students are very enthusiastic so they can learn faster than the adults when teachers give them the responsibility for performing a new task. Demirel (1999) explains the language teacher's role in EFL classes and adds that the method chosen by the teacher increase the learner's motivation. Richards and Rogers (2007) imply that a qualified language teacher can organize team work and encourage the students to join these teams. Scrivener $(1994,6)$ thinks that language teachers should know many things about methodology, but they should also know the way in which, and how their students are thinking and feeling during the class.

In Turkey, it is a fact that children do not like learning languages for different reasons. The problem can result from the teachers, their methods or behaviour in the class atmosphere. For years, linguists, researchers and language teachers have tried to solve this problem by creating more effective teaching programs. Constructivism, which seeks the learners' problems and constructs the knowledge in accordance with different experiences, can be used in mixed and crowded classrooms in Turkish Elementary schools and can help language teachers solve this problem (Ilter, 2002). Brooks (1987) states that students can learn when they study with their peers, and share their ideas with their teachers in constructivist classrooms. Constructivist classrooms enable the teachers and students to be more creative and active in the class.

\section{Aims of the Study}

The aim of this study is to investigate 'Which methods and techniques language teachers working in primary schools in Kepez Region in Antalya mostly use'.

This study also tried to understand the following problems;

1) Is there a significant difference between language teachers in using methods and techniques due to their in-service training?

2) Is there a significant difference between language teachers in using methods and techniques due to their graduation? 
3) Is there a significant difference between language teachers in using methods and techniques due to their experience?

\section{The Aim of the Study}

The aim of this study is to understand and discover the methods and techniques which are used by language teachers in Antalya. This study is limited to elementary school teachers who are teaching foreign languages in the Kepez Region of Antalya. It contains 200 language teachers.

\section{Method of the Study}

In this qualitative research paper, a questionnaire was designed to understand the language teachers' methods and techniques in EFL classes in order to be able to make comparisons among the language teachers in terms of their experience, graduation and training. Nunan $(1992,143)$ defines the questionnaire as a popular means of collecting data. The questionnaire was also examined by one linguist, one expert in testing and one expert in language education and then it was delivered to 200 language teachers who were attending a teacher training program in Antalya. They had a 1 week teacher training program on methods, techniques and new trends in EFL.

\section{Procedure}

The language teachers who participated in this study have been working in primary schools in Antalya. First of all the questionnaire was given to a sample group and it was evaluated and reorganized, then it was distributed to the whole group of teachers. After data collection, factor analysis was used in order to determine the factor structure of the data obtained. The questionnaire was factor analyzed using Bartlett's Test of Sphericity. After Bartlett's Test of Sphericity, Chi-squared distribution was found as 501.621. As it can be seen in Table 1, item loading were divided into 3 groups. Item loadings on factor 1 explain the constructive approach; item loadings on factor 2 explain the communicative approach and the item loadings on factor 3 show the traditional approach. The questionnaire was submitted to reliability test. Total reliabilities for the items $\mathrm{KMO}=0.736$. After factor analysis, the questionnaire was delivered to the language teachers. The data obtained through this questionnaire was collected under the following headings; traditional method and its techniques, communicative approach and its techniques and constructivist approach and its techniques. Each category was analysed with different tests. In Table 1, the result of factor analysis in terms of methods can be seen in three categories:

Table 1. Language Teachers' Methods in Terms of Factor Analysis Results

\begin{tabular}{|c|l|c|c|c|}
\hline $\begin{array}{c}\text { Item } \\
\text { Number }\end{array}$ & \multicolumn{1}{|c|}{ Statements } & $\begin{array}{c}\text { Factor 1 } \\
\text { (Constructivist } \\
\text { Approach) }\end{array}$ & $\begin{array}{c}\text { Factor 2 } \\
\text { (Communicative } \\
\text { Approach) }\end{array}$ & $\begin{array}{c}\text { Factor 3 } \\
\text { (Traditional } \\
\text { Approach) }\end{array}$ \\
\hline $1(11)$ & I use integrated skills in EFL class. & 0.617 & & \\
\hline $2(12)$ & I use authentic materials. & 0.749 & & \\
\hline $3(13)$ & I use songs and games in the class. & 0.776 & & \\
\hline $4(14)$ & I use internet and technology in the class. & 0.778 & & \\
\hline $5(15)$ & I use simplified literary text in the class. & 0.584 & & \\
\hline $6(7)$ & I organize pair and group work activities. & & 0.834 & \\
\hline $7(8)$ & $\begin{array}{l}\text { I use drama and role playing techniques } \\
\text { in the classroom. }\end{array}$ & & 0.846 & \\
\hline
\end{tabular}




\begin{tabular}{|l|l|l|c|c|}
\hline $8(9)$ & I use dialogues which explain daily life. & & 0.600 & \\
\hline $9(1)$ & I teach grammar only. & & & 0.660 \\
\hline $10(2)$ & I do translation during the lesson. & & & 0.645 \\
\hline $11(3)$ & I give lots of homework and make drills. & & & 0.488 \\
\hline $12(4)$ & $\begin{array}{l}\text { I make my students memorize every } \\
\text { thing. }\end{array}$ & & & 0.703 \\
\hline & Variance Rate = Total (\%52.399) & $\% 22.324$ & $\% 16.182$ & $\% 13.892$ \\
\hline & Reliability Coefficient= Total (.680) & 0.760 & 0.710 & 0.510 \\
\hline
\end{tabular}

$\mathrm{KMO}=0.736$

Bartlett's Test of Sphericity: Chi-squared distribution $=501.621, \mathrm{Sd}=66, \mathrm{P}=0.000$

\section{Findings}

Results of the language teachers' questionnaire can clearly be seen in the following tables. In order to find out whether there is a significant difference among language teachers in terms of their in-service training and methods in EFL classes, Table 2 was prepared.

Table 2. Is there a significant difference between the language teachers in using traditional method according to their in-service training?

\begin{tabular}{|c|c|c|c|c|c|c|}
\hline Traditional M. & $\mathrm{N}$ & $\bar{X}$ & $\mathrm{~S}$ & $\mathrm{Sd}$ & $\mathrm{t}$ & $\mathrm{P}$ \\
\hline Yes & 110 & 3.65 & 0.545 & \multirow{2}{*}{198} & \multirow{2}{*}{0.420} & 0.357 \\
\hline No & 90 & 3.68 & 0.609 & & & \\
\hline
\end{tabular}

$\mathrm{p}>.05$

When we analyze Table 2; it is seen that there is no significant difference between the language teachers in using traditional methods according to their in-service training. Table 3 shows the results of the communicative approach used by language teachers in terms of their in-service training.

Table 3. Is there a significant difference between language teachers in using the communicative approach according to their in-service training?

\begin{tabular}{|c|c|c|c|c|c|c|}
\hline Communicative A. & $\mathrm{N}$ & $\bar{X}$ & $\mathrm{~S}$ & $\mathrm{Sd}$ & $\mathrm{T}$ & $\mathrm{P}$ \\
\cline { 1 - 4 } Yes & 110 & 3.72 & 0.718 & \multirow{2}{*}{198} & 0.23 & \multirow{2}{*}{0.559} \\
\hline No & 90 & 3.72 & 0.723 & & & \\
\hline
\end{tabular}

$\mathrm{p}>.05$

As it can be seen in Table 3, there is no significant difference between the language teachers in using communicative methods according to their in-service training.

Table 4 shows that whether there is a significant difference between language teachers in using the constructivist approach according to their in-service training.

Table 4. Is there a significant difference between language teachers in using the constructivist approach according to their in-service training?

\begin{tabular}{|c|c|c|c|c|c|c|}
\hline Constructivist A. & N & $\bar{X}$ & S & Sd & T & P \\
\hline Yes & 110 & 3.34 & 0.623 & \multirow{2}{*}{198} & 0.349 & 0.028 \\
\hline No & 90 & 3.82 & 0.794 & & & \\
\hline $\mathrm{p}<.05$ &
\end{tabular}

After the $\mathrm{T}$ test results above, it was realized that variances were not equal, so Mann Whitney 
U- Test for independent samples was defined. Findings from Mann Whitney U-Test for independent samples are given in Table 5.

Table 5. Is there a significant difference between language teachers in using the constructivist approach according to their in-service training?

\begin{tabular}{|c|c|c|c|c|c|}
\hline Constructivist A. & N & Mean Rank & Sum of Ranks & U & P \\
\hline Yes & 110 & 98.41 & 10825 & \multirow{2}{*}{4720} & \multirow{2}{*}{0.566} \\
\hline No & 90 & 103.5 & 9274 & & \\
\hline p $>.05$ & &
\end{tabular}

As it can been seen above, there is no significant difference between the language teachers in using the constructivist approach according to their in-service training. According to the results in this part, it can be said that language teachers' methods do not change in terms of their inservice training.

When it comes to the teachers' methods in terms of their graduation, Table 6,7 and 8 were prepared. In order to find out whether there is a significant difference among the language teachers according to their graduation in using methods ANOVA was applied. Table 6 shows the result of language teachers in using the traditional method according to their graduation.

Table 6. Is there a significant difference between language teachers according to their graduation in using thetraditional method?

\begin{tabular}{|c|c|c|c|c|c|}
\hline Source & Sum of Squares & df & Mean Square & $\mathrm{F}$ & $\mathrm{P}$ \\
\hline Between Groups & 2.101 & 3 & 0.700 & \multirow{3}{*}{2.166} & \multirow{3}{*}{0.093} \\
\hline Within Groups & 63.369 & 196 & 0.323 & & \\
\hline Total & 65.470 & 199 & & & \\
\hline
\end{tabular}

As can be observed from Table $6, \mathrm{~F}=2.166$ and $\mathrm{P}>0.05$. These results explain that there is no significant difference between language teachers according to their graduation in using the traditional method.

Table 7 indicates whether there is a significant difference between language teachers according to their graduation in using communicative approach.

Table 7. Is there a significant difference between language teachers according to their graduation in using the communicative approach?

\begin{tabular}{|c|c|c|c|c|c|}
\hline Source & Sum of Squares & df & Mean Square & F & P \\
\hline Between Groups & 0.869 & 3 & 0.290 & & \multirow{2}{*}{0.556} \\
\cline { 1 - 3 } Within Groups & 102.038 & 196 & 0.521 & 0.645 \\
\hline Total & 102.936 & 199 & & & \\
\hline p $>.05$
\end{tabular}

The scores in Table 7 show $\mathrm{F}=0.556$ and $\mathrm{P}>0.05$. It means that there is no significant difference between language teachers according to their graduation in using the communicative approach.

Table 8 indicates whether there is a significant difference between language teachers according to their graduation in using the constructivist approach.

Table 8. Is there a significant difference between language teachers according to their graduation in using the constructivist approach? 


\begin{tabular}{|c|c|c|c|c|c|}
\hline Source & Sum of Squares & Df & Mean Square & F & P \\
\hline Between Groups & 0.509 & 3 & 0.170 & & \multirow{2}{*}{0.339} \\
\cline { 1 - 3 } Within Groups & 98.057 & 196 & 0.500 & 0.797 \\
\hline Total & 98.666 & 199 & & \\
\hline
\end{tabular}

$p>.05$

As can be seen in Table $8, \mathrm{~F}=0.339$ and $\mathrm{P}>0.05$. It means that there is no significant difference between language teachers according to their graduation in using the constructivist approach. In order to analyze the results in detail, ANOVA was used again. The results of ANOVA can be seen in Table 9, Table 10 and Table 11. Table 9 shows whether there is a significant difference between language teachers in using the traditional approach according to their experience.

Table 9. Is there a significant difference between the language teachers in using the traditional approach according to their experience?

\begin{tabular}{|c|c|c|c|c|c|}
\hline Source & Sum of Squares & df & Mean Square & F & P \\
\hline Between Groups & 3.712 & 3 & 1.237 & & \multirow{2}{*}{3.927} \\
\cline { 1 - 3 } Within Groups & 61.758 & 196 & 0.315 & 0.009 \\
\hline Total & 65.470 & 199 & & & \\
\hline $\mathrm{p}<.05$
\end{tabular}

As can be observed in Table $9, \mathrm{~F}=3.927$ and $\mathrm{P}<0.05$. It means that that there is no significant difference between language teachers according to their experience in using traditional approach.

Table 10 indicates whether there is a significant difference between language teachers in using the communicative approach according to their experience.

Table 10. Is there a significant difference between the language teachers in using communicative approach according to their experience?

\begin{tabular}{|c|c|c|c|c|c|}
\hline Source & Sum of Squares & df & Mean Square & F & P \\
\hline Between Groups & 1.507 & 3 & 0.502 & \multirow{2}{*}{0.971} & \multirow{2}{*}{0.407} \\
\cline { 1 - 4 } Within Groups & 101.399 & 196 & 0.517 & & \\
\hline Total & 102.906 & 199 & & \\
\hline
\end{tabular}

$\mathrm{p}>.05$

As can be observed from Table $10, \mathrm{~F}=0.971$ and $\mathrm{P}>0.05$. It means that that there no significant difference between language teachers in using the communicative approach according to their experience.

Table 11 shows whether there is a significant difference between language teachers in using the constructivist approach according to their experience.

Table 11. Is there a significant difference between language teachers in using the constructivist approach according to their experience?

\begin{tabular}{|c|c|c|c|c|c|}
\hline Source & Sum of Squares & df & Mean Square & F & P \\
\hline Between Groups & 6.947 & 3 & 2.316 & & \multirow{2}{*}{4.954} \\
\cline { 1 - 3 } Within Groups & 91.619 & 196 & 0.467 & & \\
\cline { 1 - 3 } Total & 98.566 & 199 & & & \\
\hline
\end{tabular}

$\mathrm{p}<.05$

As it can be observed in Table $11, \mathrm{~F}=4.954$ and $\mathrm{P}<0.05$. It means that that there is a significant difference between language teachers in using the constructivist approach according to their 
experience.

In order to find out the differences within groups in using the constructivist approach, the Scheffe test was used in terms of their experience. According to the test results, the following scores were categorized; the language teachers' experience of between $1-5$ years $X=3.51$, language teachers' experience of between 6-10 years $X=3.30$, language teachers' experience of between $11-15$ years $X=2.93$ and of 16 years and above $X=3.53$. These results indicate that the most experienced teachers use the constructivist approach in EFL classes.

When the communicative approach results were evaluated, it can be seen that teachers whose experience is between 1-5 years $X=3.70$, the teachers whose experience is between 6-10 years $X=3.72$, the teachers whose experience is between $11-15$ years $X=3.66$ and the teachers whose experience is 16 years and above $X=4.05$. These results also show that the most experienced teachers use the communicative approach in EFL classes.

When the traditional approach results were evaluated, it can be seen that teachers whose experience is between 1-5 years $X=3.79$, teachers whose experience is between 6-10 years $\mathrm{X}=3.60$, teachers whose experience is between $11-15$ years $\mathrm{X}=3.68$ and teachers whose experience is 16 yearsand above $X=3.26$. The results of this test show that teachers who have experience of between 1-5 years mostly use the traditional approach.

\section{Results and Discussion}

The overall results of the questionnaire show that there is no significant difference among language teachers' methods in terms of their in-service training in the Antalya Kepez region. Whether they had in-service training or not, does not affect the language teachers' types of methods in EFL classes. The findings based on the language teachers' types of method in terms of their graduation indicates there is no significant difference among the language teachers' types of method in terms of their graduation in EFL classes. Although the participants are from different departments such as linguistics, literature and language teaching, they all use the same methods and techniques in EFL classes. The data obtained from the research question 3 shows that there is a significant difference between language teachers' method types in terms of their experience. It can be understood that experienced language teachers have always been interested in new methods. It can also be seen that the young and inexperienced language teachers mostly use traditional methods in their classes. Thus, there is a close relationship among language teachers' types of method in terms of their experience. This analysis of data shows that experienced teachers like activities and methods which are new. Experienced teachers also want to be equipped with new knowledge and trends in EFL.

Considering the results discussed above, it is suggested that inexperienced teachers learn the importance of new methods and trends in the EFL field. Teacher trainers and academicians should help young language teachers apply new trends and methods in the EFL field. It can also be suggested that young and experienced teacher should join the teacher training programs together in order to share new ideas. Randall and Thornton (2001) support this idea and state that these kinds of programs provide a non-judgmental atmosphere and make language teachers more autonomous and reflective. It can be said that many young language teachers seem knowledgeable about the new methods but they have some hesitations in usingthem in their classes for various reasons. They need to be encouraged and to obtain more experience in their careers and they also need to be guided by their experienced colleagues. Finally, it is suggested that when they meet their experienced colleagues, they can benefit from not only their teaching methods but also from their experience obtained during their teaching career. 


\section{REFERENCES}

Azar, A. (2011). “Türkiye’deki Öğretmen Eğitimi Üzerine Bir Söylem: Nitelik mi, Nicelik mi?”. Yüksekögretim ve Bilim Dergisi, 1(1). 36-38.

Brewster, J., Ellis, G., \& Girard, D. (2004). The Primary English Teacher's Guide. Essex: Pearson

Brooks, M. (1987). "Curriculum Development from a Constructivist Perspective". Educational Leadership, 44(4), 63-67.

Bloom, B. S. (1998). Insan Nitelikleri ve Okulda Öğrenme. Milli Eğitim Basımevi.

Bursalığlu, Z. (1994). Okul Yönetiminde Yeni Yapı ve Yavranış. Ankara: Pegem Yayınları.

Cameron, L. (2009). Teaching Languages to Young Learners. Cambridge: CUP.

Demirel, Ö. (1999). İlköğretim Okullarında Yabancı Dil Öğretimi. Milli Eğitim Basımevi.

Freeman-Larsen, D. (2010). Techniques and Principles in Language Teaching. New York: OUP.

Harmer, J. (2005). The Practice of English Language Teaching. England: Longman.

İlter, G. B. (2002). Oluşturmacı Yaklaşımla İngilizce Yazma Becerisini Geliştirmenin Öğrenci Başarısına Etkisi. Yayınlanmamış Doktora Tezi/Unpublished Doctorate Thesis. Ankara.

Jones, V. F., \& Jones, L. S. (1998). Comprehensive classroom management: Creating Communities of Support and Solving Problems (5th ed.). Boston: Allyn \& Bacon.

Nunan, D. (1992). Research Methods in Language Learning. Cambridge: CUP.

Sönmez, V. (1994). Program Gelişstirmede Öğretmen El Kitabı. Ankara: Anı Yayınc1lık.

Randall, M., \& Thornton, B. (2001). Advising and Supporting Teachers. Cambridge: CUP.

Richards, J. C., \& Rodgers, T. (2007). Approaches and Methods in Language Teaching. Cambridge: CUP.

Roth, G. (1998). Teaching Very Young Children. London: Richmond Publishing.

Scott, W. A., \& Ytreberg, L. H. (2010). Teaching English to Children. Edinburg: Longman.

Scrivener, J. (1994). Learning Teaching. Oxford: Heineman.

TED. (2009). Öğretmen Yeterlikleri. Ankara: Okan Matbaacılık Basım Yayım.

Vale, D., \& Feunteun, A. (2002). Teaching Children English. Cambridge: CUP.

Wright, A., Betteridge, D., \& Buckby, M. (2007). Games for Language Learning. Cambridge: CUP. 